\title{
Group Transfer Polymerization of Methacryl-Type Poly(2-oxazoline) Macromonomers
}

\author{
Yasuo Shimano, ${ }^{\dagger}$ Kumiko Sato, and Shiro Kobayashi* \\ Department of Chemical and Biological Engineering, Hachinohe National College of Technology, \\ Tamonoki, Hachinohe 039-1192, Japan \\ * Department of Materials Chemistry, Graduate School of Engineering, \\ Kyoto University, Kyoto, 606-8501, Japan
}

(Received November 16, 1998)

\begin{abstract}
Group transfer polymerization (GTP) of methacrylate-terminated poly(2-alkyl-2-oxazoline) macromonomers (MA-PROZO- $n$ 3; $\mathrm{R}=$ Me and $n$-Bu; $n$, degree of polymerization) was examined using 1-methoxy-1-(trimethylsiloxy)-2-methyl1 -propene and nucleophiles as the initiator and catalyst, respectively, at 24 or 50 C. MA-PROZO- $n 3$ ( $\mathrm{R}=n$-Bu; $n=3,14$, and 31) was polymerized using tetra- $n$-butylammonium fluoride as the catalyst in tetrahydrofuran (THF) to provide poly(MA-PROZO-n)s $\left(4 ; \mathrm{R}=n\right.$-Bu) with $M_{n}$ up to 37600 . GTP of $\mathbf{3}(\mathrm{R}=\mathrm{Me} ; n=14$ and 30$)$ was carried out by use of $\mathrm{KHF}_{2}$ as the catalyst in $\mathrm{CH}_{3} \mathrm{CN}$ or $\mathrm{CD}_{3} \mathrm{CN}$ to produce $4(\mathrm{R}=\mathrm{Me})$ with maximum $M_{n}$ up to $17300 . M_{w} / M_{n}$ of the 4 given from 3 of $n \geq 14$ was narrow (1.08-1.12). Rate of the GTP of the macromonomers 3 decreased with increase in $n$ and concentrations of macromonomers. Maximum conversion of macromonomers $\mathbf{3}$ was obtained at relatively lower concentration of $\mathbf{3}$, generally 89-95\%. Polymer $4(\mathrm{R}=n-\mathrm{Bu})$ was coupled in situ with $p$-bis(bromomethyl)benzene or propagating species of living poly $(2-n-$ butyl-2-oxazoline)s, to provide chain extended poly(MA-PROZO- $n) \mathrm{s}(\mathbf{5} ; \mathrm{R}=n$ - $\mathrm{Bu})$ or block copolymers (6). From characteristics of the reactivity of $\mathbf{3}$ and $\mathbf{4}$ and narrow molecular weight distribution of $\mathbf{4}$, living nature of present polymerization was suggested. KEY WORDS Macromonomer/Polyoxazoline/Group Transfer Polymerization/Living Polymerization / End-Capping / Block Copolymer /
\end{abstract}

Living poly(2-alkyl-2-oxazoline) (PROZO) (1) obtained by ring-opening polymerization ${ }^{1}$ of 2 -alkyl-2oxazoline (ROZO) can be terminated by methacrylate anions to provide methacrylate-terminated PROZO macromonomers (MA-PROZO- $n$ 3; $n$, degree of polymerization of ROZO). ${ }^{2}$ Macromonomers 3 have been synthesized by acylation of alcohols (2) produced by hydrolysis of $\mathbf{1}$, with methacryloyl chloride. ${ }^{2}$ PROZO 1 of poly $(N$-acylethylenimine $)$ can be regarded as a polymer homologue of polar aprotic solvents such as $N, N$ dimethylacetamide, showing hydrophilic $(\mathrm{R}=\mathrm{Me}, \mathrm{Et})$ or hydrophobic (carbon number of $\mathrm{R} \geq 4$ ) properties. $^{1}$ Amphiphilic copolymers have been synthesized by the copolymerization of $\mathbf{3}$ with methyl methacrylate or styrene. ${ }^{3}$ Previously we examined radical polymerizability of 3 . The reactivity was strongly affected by carbon number of the alkyl groups and by PROZO chain length. ${ }^{4}$ Reactivity in radical copolymerization of vinylbenzylterminated PROZO macromonomers with ordinary vinyl monomers was studied. ${ }^{5}$

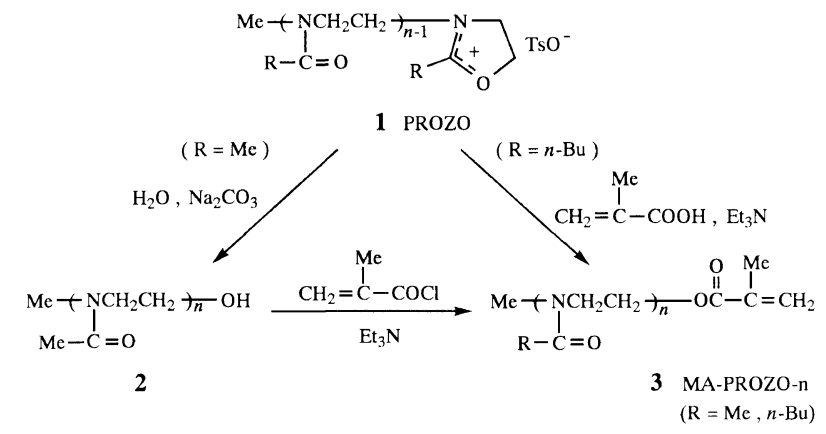

Scheme 1.

† To whom correspondence should be addressed.
Webster performed living polymerization of acrylic monomers initiated by silyl ketene acetals in the presence of a catalyst such as fluoride and bifluoride anion. ${ }^{6}$ As for the group transfer polymerization (GTP) of macromonomers, Asami reported living GTP of methacrylateterminated polystyrene macromonomers initiated by a silyl ketene acetal. ${ }^{7}$ In the polymerization of the PROZO macromonomers, ionic nor ionic-like technique is not known, and should facilitate the production of living poly(macromonomer)s which may have narrow molecular weight distribution and may be utilized for introduction of functional groups. Radical polymerization seems not so easy to provide such living polymers.

The present paper describes GTP of MA-PROZO- $n \mathbf{3}$ ( $\mathrm{R}=\mathrm{Me}$ and $n-\mathrm{Bu})$ and examination on living nature of the GTP and on utilization of the propagating species for a synthesis of block copolymers by termination with living PROZO and for chain extension by end-capping. This new method provides an amphiphilic graft polymer having hydrophobic methacrylate main chain and hydrophilic PROZO $(R=M e)$ graft chain.

\section{EXPERIMENTAL}

\section{Materials}

Tetrahydrofuran (THF) and $\mathrm{Et}_{2} \mathrm{O}$ were distilled over sodium wire. $\mathrm{CH}_{3} \mathrm{CN}$ and $\mathrm{CD}_{3} \mathrm{CN}$ were purified by distillation over $\mathrm{P}_{2} \mathrm{O}_{5}$. Solvents, $\mathrm{CHCl}_{3}, \mathrm{CDCl}_{3}$, petroleum ether, benzene, hexane, and methanol were distilled from molecular sieves. $N, N$-dimethylformamide (DMF) was distilled from $\mathrm{CaH}_{2}$. 2-Methyl-2-oxazoline (MeOZO) was stirred with $\mathrm{KOH}$ and distilled. Methyl tosylate (MeOTs) and methacryloyl chloride were distilled in vacuo. Methacrylic acid and $p$-bis(bromomethyl)benzene (BMB) were dried with molecular sieves and distilled. 2-n-Butyl-2-oxazoline (BuOZO) $)^{8}$ and 1-methoxy-1- 
(trimethylsiloxy)-2-methyl-1-propene (MTS) ${ }^{9}$ were prepared according to the literature. Tris(dimethylamino)sulfur(trimethylsilyl)difluoride (TASF), hexane solution $(1.5 \mathrm{M})$ of $n$-butyl lithium and THF solution $(1.0 \mathrm{M})$ of tetra- $n$-butylammonium fluoride (TBAF) were used as received. 1,1-Diphenyl-2-picrylhydrazyl (DPPH) was recrystallized from petroleum ether. $\mathrm{KHF}_{2}$ was dried in vacuo at $150^{\circ} \mathrm{C}$.

\section{Measurements}

${ }^{1}$ H NMR spectra were recorded on a Jeol JNM FX60Q spectrometer with tetramethylsilane as the standard. IR spectra were measured by a Jasco IR-810 spectrophotometer. GPC analysis was performed using a Shimadzu LC-10AD chromatograph equipped with a Shimadzu RID-6A RI detector. For analysis of the products given from MA-PBuOZO- $n$ (3), GPC columns, Shodex A-803 and Jasco Fine Pack Gel-101 were connected in series (Column A), and $\mathrm{CHCl}_{3}$ was used as the eluent, while for analysis of the products given from MA-PMeOZO$n$ (3), two Tosoh $\mathrm{TSK}_{\text {gel }} \mathrm{GMH}_{\mathrm{HR}-\mathrm{M}}$ columns were connected in series (Column B), and DMF was used as the eluent at $60^{\circ} \mathrm{C}$, at a flow rate of $0.8 \mathrm{~mL} \mathrm{~min}^{-1}$ in all runs. Molecular weight data in GPC were obtained with PMeOZO standards.

\section{Macromonomers}

MA-PROZO- $n$ (3) was prepared as follows (Scheme 1). ${ }^{2} \mathrm{ROZO}$ was heated with MeOTs initiator in $\mathrm{CH}_{3} \mathrm{CN}$ at $80^{\circ} \mathrm{C}$ for $20 \mathrm{~h}$ to form living PROZO (1). 2Oxazolinium salt at the chain end of $1(\mathrm{R}=\mathrm{Me})$ was hydrolyzed by heating with $\mathrm{H}_{2} \mathrm{O}$ and $\mathrm{Na}_{2} \mathrm{CO}_{3}$ at $100^{\circ} \mathrm{C}$ for $20 \mathrm{~h}$ to give the PMeOZO-alcohols (2), which was acylated by methacryloyl chloride with $\mathrm{Et}_{3} \mathrm{~N}$ in $\mathrm{CH}_{3} \mathrm{CN}$ to produce the MA-PMeOZO- $n$ (3). On the other hand, MA-PBuOZO- $n$ (3) was prepared by terminating the propagating species $1(\mathrm{R}=n$ - $\mathrm{Bu})$ with methacrylic acid and $\mathrm{Et}_{3} \mathrm{~N}$ at $80^{\circ} \mathrm{C}$. Macromonomers 3 were purified by reprecipitation from $\mathrm{CHCl}_{3}$ solution with $\mathrm{Et}_{2} \mathrm{O}(\mathrm{R}=\mathrm{Me})$ or hexane $(\mathrm{R}=n-\mathrm{Bu})$ as non-solvents.

The results are shown in Table I. $M_{n}$ of $\mathbf{3}$ was determined by both ${ }^{1} \mathrm{H}$ NMR and GPC. In ${ }^{1} \mathrm{H}$ NMR, signal integration ratios of $\mathrm{NCH}_{2}$ protons $(\delta 3.4-3.6$ ) to $\mathrm{NCH}_{3}$ protons $(\delta 3.0)$ at $\omega$ ends gave the macromonomer chain length $n\left(D P_{n}\right)$, from which $M_{n}$ was calculated. GPC was measured through Column A described above in $\mathrm{CHCl}_{3}$ as the eluent using PMeOZO standards prepared by the polymerization of $\mathrm{MeOZO}$ by MeOTs as the initiator. Molecular weight distributions of 3 were generally narrow reflecting living nature of the polymerization: $M_{w} / M_{n}=1.12-1.32$. Functionality $(F)$, i.e., the number of methacrylate groups per molecules of 3 was determined from the signal integration ratios of vinyl protons ( $\delta 5.60$ and 6.03 ) in methacrylate groups to $\mathrm{NCH}_{3}$ protons $(\delta 3.0)$ at $\omega$ end.

\section{GTP of MA-PROZO Macromonomers (3)}

a) $M A-P B u O Z O$ Macromonomers. Typical runs were as follows.

1) Polymerization of MA-PBuOZO-n (Entry 5): To a mixture of THF $(6.6 \mathrm{~mL}), 0.167 \mathrm{~g} 0.96 \%$ MTS solution in THF $\left(4.57 \times 10^{-3} \mathrm{mmol}\right)$, and $0.036 \mathrm{~g} 6.55 \times 10^{-3} \%$ solution of TBAF in THF $\left(9.02 \times 10^{-6} \mathrm{mmol}\right)$ was added
Table I. MA-PROZO macromonomers (3)

\begin{tabular}{|c|c|c|c|c|c|}
\hline \multirow{2}{*}{$\begin{array}{l}\text { Macromonomer } \\
\mathbf{3}\end{array}$} & \multicolumn{2}{|c|}{$M_{n}$} & \multirow{2}{*}{$D P_{n}^{a}$} & \multirow{2}{*}{$\frac{M_{w}{ }^{\mathrm{a}}}{M_{n}}$} & \multirow{2}{*}{$F^{\mathrm{b}}$} \\
\hline & NMR & GPC & & & \\
\hline MA-PMeOZO-14 & 1290 & 1250 & 13.5 & 1.12 & 0.98 \\
\hline MA-PMeOZO-30 & 2780 & 2630 & 29.7 & 1.17 & 0.98 \\
\hline MA-PBuOZO-3 & 510 & 490 & 3.0 & 1.32 & 1.00 \\
\hline MA-PBuOZO-14 & 1920 & 1840 & 13.7 & 1.13 & 1.00 \\
\hline MA-PBuOZO-31 & 4390 & 4020 & 30.8 & 1.19 & 0.99 \\
\hline
\end{tabular}

a Determined by GPC using PMeOZO standards. ${ }^{\mathrm{b}}$ Functionality, determined by ${ }^{1} \mathrm{H}$ NMR

dropwise $2.804 \mathrm{~g} 6.99 \%$ solution of MA-PBuOZO-3 in THF $(0.40 \mathrm{mmol})$ under argon, and the solution was heated at $50^{\circ} \mathrm{C}$ for $175 \mathrm{~h}$ in a sealed tube. The resulting solution was dried in vacuo, and the residue was dissolved in $\mathrm{CHCl}_{3}$. The solution was added to hexane and the precipitate was collected, and dried giving $0.183 \mathrm{~g}$ of solid material. GPC analysis of the product gave macromonomer conversion to be $78 \%, M_{n}$ of poly(macromonomer $)$ to be $23000\left(D P_{n}=46.5\right)$, and $M_{w} / M_{n}=1.25$. ${ }^{1} \mathrm{H}$ NMR $\left(\mathrm{CDCl}_{3}\right): \delta=4.20\left(\mathrm{t}, \mathrm{OCH}_{2}-\mathrm{C}-\mathrm{N}\right), 3.58(\mathrm{~s}$, $\left.\mathrm{CH}_{3} \mathrm{OC}=\mathrm{O}\right), 3.36\left(\mathrm{br}, \mathrm{NCH}_{2}\right), 3.0\left(\mathrm{br}, \mathrm{NCH}_{3}\right), 2.0-2.5$ (br, $\mathrm{CH}_{2} \mathrm{C}=\mathrm{O}$ ), $1.0-1.7$ (br, $\mathrm{CCH}_{2} \mathrm{CH}_{2} \mathrm{C}$ ), 0.93 (br, $\mathrm{CH}_{3} \mathrm{C}$ ).

2) Determination of Conversion by GPC (Entry 1): To a mixture of THF (7.2 mL), $0.882 \mathrm{~g} 0.96 \%$ MTS solution in THF $\left(0.802 \mathrm{~g} ; 4.86 \times 10^{-2} \mathrm{mmol}\right)$, and $0.190 \mathrm{~g}$ of $6.55 \times 10^{-3} \%$ solution of TBAF in THF $\left(4.76 \times 10^{-5}\right.$ mmol) was added dropwise $3.448 \mathrm{~g} 6.99 \%$ solution of MA-PBuOZO-3 in THF (0.491 mmol) under argon, and the solution formed was divided in seven equal parts. Each part in a sealed tube was stirred at $24^{\circ} \mathrm{C}$ within the prescribed time interval and dried in vacuo. GPC analysis of the residues using $\mathrm{CHCl}_{3}$ as the eluent gave macromonomer conversions $p$ on the basis of following equation, under assumption that the peak area per unit weight of 4 was not different from that of macromonomers.

$$
p=S_{\mathrm{m}} /\left(S_{\mathrm{p}}+S_{\mathrm{m}}\right)
$$

where $S_{\mathrm{p}}$ is the peak area of poly(MA-PROZO- $n$ ), and $S_{\mathrm{m}}$ is the peak area of MA-PROZO- $n$.

b) $M A-P M e O Z O$ Macromonomers. Typical runs were as follows.

l) Polymerization of MA-PMeOZO-n (Entry 12): A mixture of MA-PMeOZO-14 (0.132 g; $0.106 \mathrm{mmol})$, $0.247 \mathrm{~g} 0.74 \%$ MTS solution in $\mathrm{CH}_{3} \mathrm{CN}\left(1.05 \times 10^{-2}\right.$ $\mathrm{mmol}), \mathrm{KHF}_{2}\left(0.077 \mathrm{mg} ; 9.91 \times 10^{-4} \mathrm{mmol}\right)$, and $\mathrm{CH}_{3} \mathrm{CN}(11.5 \mathrm{~mL})$ was heated at $50^{\circ} \mathrm{C}$ under argon for $235 \mathrm{~h}$. The resulting solution was added to $\mathrm{Et}_{2} \mathrm{O}$ to precipitate a polymeric material, which was dissolved in $\mathrm{CH}_{3} \mathrm{CN}$ and filtered. The filtrate was added to $\mathrm{Et}_{2} \mathrm{O}$ and the precipitate was dried in vacuo giving $0.125 \mathrm{~g}$ of solid material. GPC analysis of the product gave macromonomer conversion to be $82 \%, M_{n}$ of poly(macromonomer $)$ to be $11220\left(D P_{n}=8.8\right)$, and $M_{w} / M_{n}=1.12$. ${ }^{1} \mathrm{H}$ NMR $\left(\mathrm{CD}_{3} \mathrm{CN}\right): \delta=4.22\left(\mathrm{t}, \mathrm{OCH}_{2}-\mathrm{C}-\mathrm{N}\right), 3.57(\mathrm{~s}$, $\mathrm{CH}_{3} \mathrm{OC}=\mathrm{O}$ ), $3.38\left(\right.$ br, $\mathrm{NCH}_{2}$ ), $2.96\left(\right.$ br, $\left.\mathrm{NCH}_{3}\right), 2.0$ (br, $\mathrm{CH}_{3} \mathrm{C}=\mathrm{O}$ ).

2) Determination of Conversion by ${ }^{1} H \mathrm{NMR}$ (Entry 11): In a $5 \mathrm{~mm}$ o.d. NMR tube $0.025 \mathrm{~g}$ of MA-PMeOZO- 
$14\left(2.00 \times 10^{-2} \mathrm{mmol}\right), 0.094 \mathrm{~g} 0.35 \%$ MTS solution in $\mathrm{CD}_{3} \mathrm{CN}\left(1.89 \times 10^{-3} \mathrm{mmol}\right), \mathrm{KHF}_{2}(0.014 \mathrm{mg} ; 1.78 \times$ $\left.10^{-4} \mathrm{mmol}\right)$, and $\mathrm{CD}_{3} \mathrm{CN}(0.4 \mathrm{~mL})$ were mixed under argon, sealed, and allowed to stand at $24^{\circ} \mathrm{C}$ within a prescribed time and chilled to quench at $-78^{\circ} \mathrm{C}$. Decrease of signal integration ratio of $\delta 5.04$ and 5.59 $\left(\mathrm{CH}_{2}=\mathrm{C}\right.$, methacryloyl $)$ to $\delta 4.24\left(\mathrm{t}, \mathrm{OCH}_{2}\right)$ in ${ }^{1} \mathrm{H} \mathrm{NMR}$ gave macromonomer conversion.

\section{Reaction of Living Poly(macromonomer)s (4)}

a) Termination by $B M B$. To a mixture of THF $(0.9 \mathrm{~mL})$, $1.287 \mathrm{~g} 0.96 \%$ MTS solution in THF $\left(7.09 \times 10^{-2} \mathrm{mmol}\right)$, and $0.277 \mathrm{~g} 6.55 \times 10^{-3} \%$ solution of TBAF in THF $\left(6.95 \times 10^{-5} \mathrm{mmol}\right)$ was added dropwise $3.892 \mathrm{~g} 6.99 \%$ solution of MA-PBuOZO-3 in THF $(0.555 \mathrm{mmol})$ under argon, and the solution was heated at $50^{\circ} \mathrm{C}$ for $48 \mathrm{~h}$. GPC analysis of $0.2 \mathrm{~mL}$ aliquot gave macromonomer conversion as $82 \%$ and $M_{n}$ of poly(macromonomer) to be 3500 $\left(D P_{n}=6.8\right)$. To the reaction solution were added TASF $\left(20.7 \mathrm{mg} ; 7.52 \times 10^{-2} \mathrm{mmol}\right)$ and BMB $(9.3 \mathrm{mg} ; 3.54 \times$ $10^{-2} \mathrm{mmol}$ ) at $-78^{\circ} \mathrm{C}$, and stirred for $24 \mathrm{~h}$. The solution was dried in vacuo. The residue was dissolved in $\mathrm{CHCl}_{3}$, precipitated in hexane, filtered, and dried to give $0.258 \mathrm{~g}$ of solid material. GPC analysis of the product gave conversion of the poly(macromonomer) to be $94 \%$ and $M_{n}$ to be $8800 .{ }^{1} \mathrm{H}$ NMR $\left(\mathrm{CDCl}_{3}\right): \delta=7.1-7.3(\mathrm{~m}$, $\left.\mathrm{C}_{6} \mathrm{H}_{4}\right), 4.50\left(\mathrm{~s}, \mathrm{CH}_{2} \phi\right), 4.17\left(\mathrm{t}, \mathrm{OCH}_{2}-\mathrm{C}-\mathrm{N}\right), 3.60$ (s, $\left.\mathrm{CH}_{3} \mathrm{OC}=\mathrm{O}\right), 3.40\left(\mathrm{br}, \mathrm{NCH}_{2}\right), 3.0\left(\mathrm{br}, \mathrm{NCH}_{3}\right), 2.0-2.5$ (br, $\mathrm{CH}_{2} \mathrm{C}=\mathrm{O}$ ), 1.0-1.7 (br, $\mathrm{CCH}_{2} \mathrm{CH}_{2} \mathrm{C}$ ), 0.95 (br, $\left.\mathrm{CH}_{3} \mathrm{C}\right)$.

b) Termination by Living PBuOZO. To a mixture of THF $(6.5 \mathrm{~mL}), 2.145 \mathrm{~g} 0.96 \%$ solution of MTS in THF $(0.118 \mathrm{mmol})$, and $0.461 \mathrm{~g} 6.55 \times 10^{-3} \%$ solution of TBAF in THF $\left(1.16 \times 10^{-4} \mathrm{mmol}\right)$ was added dropwise $14.845 \mathrm{~g} 6.99 \%$ solution of MA-PBuOZO-3 in THF $(2.115 \mathrm{mmol})$ under argon, and the solution was heated at $50^{\circ} \mathrm{C}$ for $48 \mathrm{~h}$. GPC analysis of $0.1 \mathrm{~mL}$ aliquot gave macromonomer conversion as $76 \%$ and $M_{n}$ of poly(macromonomer) 4 to be $8200\left(D P_{n}=16.4\right)$. Separately, a mixture of MeOTs $(0.023 \mathrm{~g} ; 0.124 \mathrm{mmol})$, BuOZO $\left(0.207 \mathrm{~g} ; 1.627 \mathrm{mmol} ;[\mathrm{BuOZO}]_{0} /[\mathrm{MeOTs}]_{0}=13.1\right)$, and $\mathrm{CH}_{3} \mathrm{CN}(1.0 \mathrm{~mL})$ was heated at $80 \mathrm{C}$ for $24 \mathrm{~h}$ under argon to provide living $\mathrm{PBuOZO}(1)$. An aliquot $(0.1 \mathrm{~mL})$ was analysed by GPC using the Column A to give $M_{n}$ to be $1820\left(D P_{n}=12.8\right)$. To the polymerization solution given from MA-PBuOZO-3 were added TASF (0.035 g; $0.127 \mathrm{mmol})$ and a solution of $1(\mathrm{R}=n-\mathrm{Bu} ; n=13)$ at $-78^{\circ} \mathrm{C}$, and stirred for $24 \mathrm{~h}$. The solution was dried in vacuo. The residue was dissolved in $\mathrm{CHCl}_{3}$, precipitated in hexane, filtered, and dried to give $1.082 \mathrm{~g}$ of solid material. GPC analysis of the product gave conversions of living polymers to be $100 \%$ and $M_{n}$ as $12600 .{ }^{1} \mathrm{H}$ NMR $\left(\mathrm{CDCl}_{3}\right): \delta=4.14$ (t, $\left.\mathrm{OCH}_{2}-\mathrm{C}-\mathrm{N}\right), 3.37$ (br, $\mathrm{NCH}_{2}$ ), 3.0 (br, $\mathrm{NCH}_{3}$ ).

\section{RESULTS AND DISCUSSION}

\section{Group Transfer Polymerization}

GTP of MA-PROZO- $n 3$ was examined using MTS as the initiator. GTP of MA-PBuOZO- $n$ is described below. The polymerization was carried out using TBAF as the catalyst in THF at 24 and $50^{\circ} \mathrm{C}$. MA-PBuOZO- $n$ was readily soluble in THF. Macromonomer concentra-

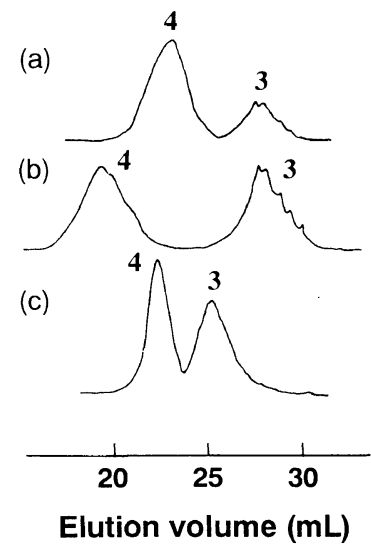

Figure 1. GPC curves of GTP products. (a) Entry 2: [MA-PBuOZO$3]_{0}:[\mathrm{I}]_{0}=10.1$; temp, $50 \mathrm{C}$ : time, $24 \mathrm{~h}$. Conversion $=76 \%$. (b) Entry 5: $[\mathrm{MA}-\mathrm{PBuOZO}-3]_{0} /[\mathrm{I}]_{0}=43.5$; temp, $50 \mathrm{C}$ : time, $24 \mathrm{~h}$. Conversion $=$ $55 \%$. (c) Entry 8: $[\mathrm{MA}-\mathrm{PBuOZO}-14]_{0} /[\mathrm{I}]_{0}=9.8$; temp, $50 \mathrm{C}$; time, $48 \mathrm{~h}$. Conversion $=39 \%$. I, initiator $(\mathrm{MTS})$.

tion was around 40 or $9 \mathrm{mmol} \mathrm{L}^{-1}$, and feed ratio of macromonomer to initiator $\left([\mathrm{M}]_{0} /[\mathrm{I}]_{0}\right)$ was close to 10 or 40 . After the reaction, the polymerization mixture was dried in vacuo. The residue was dissolved in $\mathrm{CHCl}_{3}$ and the solution was added to hexane to precipitate a mixture of poly(MA-PBuOZO- $n$ )s (4) and unreacted macromonomers. By use of TASF as the catalyst, no polymerization took place. Molecular weights of the products and conversion were estimated by GPC using $\mathrm{CHCl}_{3}$ assuming that the peak area per unit weight of $\mathbf{4}$ was not different from that of the macromonomers.

In the case of MA-PMeOZO- $n$, GTP was examined using $\mathrm{KHF}_{2}$ as the catalyst in $\mathrm{CH}_{3} \mathrm{CN}$ or $\mathrm{CD}_{3} \mathrm{CN}$. THF could not be used for the reaction solvent because of poor solubility of MA-PMeOZO- $n$. The polymerization reaction was conducted with macromonomer concentration being around 40 or $9 \mathrm{mmol} \mathrm{L}^{-1}$, and with feed ratio nearly 10 at 24 or $50^{\circ} \mathrm{C}$. Molecular weights of the products were measured by GPC using DMF as the eluent. Polymerization could be observed only by $\mathrm{KHF}_{2}$ as the catalyst, and was not detected by TASF or TBAF. This is consistent with GTP of methyl methacrylate. ${ }^{10}$

GPC curves of the products provided by GTP of MA-PBuOZO-n (3) are shown in Figure 1. Polymerization of MA-PBuOZO-3 with $[\mathrm{M}]_{0} /[\mathrm{I}]_{0}=43.5$ produced poly(MA-PBuOZO-3) 4 with higher molecular weight in lower conversion $(55 \%)$ (b), but the polymerization of the same monomer with $[\mathrm{M}]_{0} /[\mathrm{I}]_{0}=10.1$ gave the polymer with lower molecular weight in higher conversion $(76 \%)$ (a), showing increase in the feed ratio to decrease the polymerization rate, since the higher viscosity of polymerization system brought by higher molecular weight of produced polymer should depress more strongly the diffusion of growing sites and macromonomers to retard propagation reaction. MAPBuOZO-14 gave 4 of higher molecular weight in lower conversion compared to MA-PBuOZO-3 at similar feed ratio (c). Longer chain length $(n)$ of $\mathbf{3}$ should increase solution viscosity and segment density around growing ends to suppress the diffusion of reactants.

Time dependence of macromonomer conversion in the polymerization of MA-PBuOZO- $n(n=3$ and 14$)$ and MA-PMeOZO-14 under macromonomer concentration 
GTP of Poly(2-oxazoline) Macromonomers

Table II. Group transfer polymerization of MA-PROZO macromonomers (3) ${ }^{\mathrm{a}}$

\begin{tabular}{|c|c|c|c|c|c|c|c|c|c|c|c|}
\hline \multirow{2}{*}{ Entry } & \multicolumn{3}{|c|}{3} & \multirow{2}{*}{$\frac{[\mathrm{M}]_{0}{ }^{\mathrm{b}}}{[\mathrm{I}]_{0}}$} & \multirow{2}{*}{ Cat." } & \multirow{2}{*}{$\frac{\text { Temp }}{{ }_{\mathrm{C}}}$} & \multirow{2}{*}{$\frac{\text { Time }}{\mathrm{h}}$} & \multirow{2}{*}{$\frac{\text { Conversion }^{\mathrm{d}}}{\%}$} & \multirow{2}{*}{$M_{n}^{\mathrm{d}}$} & \multirow{2}{*}{$D P_{n}{ }^{\mathrm{d}}$} & \multirow{2}{*}{$\frac{M_{w}{ }^{\mathrm{d}}}{M_{n}}$} \\
\hline & $\mathrm{R}$ & $n$ & $\mathrm{mmol} \mathrm{L}^{-1}$ & & & & & & & & \\
\hline 1 & $n-\mathrm{Bu}$ & 3 & 40.8 & 10.1 & TBAF & 24 & 196 & 85 & 4730 & 9.3 & 1.41 \\
\hline 2 & $n-\mathrm{Bu}$ & 3 & 40.8 & 10.1 & TBAF & 50 & 162 & 83 & 5860 & 11.6 & 1.88 \\
\hline 3 & $n-\mathrm{Bu}$ & 3 & 8.8 & 10.7 & TBAF & 24 & 246 & 95 & 5760 & 11.4 & 1.28 \\
\hline 4 & $n-\mathrm{Bu}$ & 3 & 40.8 & 43.5 & TBAF & 50 & 175 & 78 & 23000 & 46.5 & 1.25 \\
\hline 6 & $n-\mathrm{Bu}$ & 14 & 41.5 & 9.8 & TBAF & 24 & 180 & 51 & 12300 & 5.8 & 1.09 \\
\hline 7 & $n-\mathrm{Bu}$ & 14 & 41.5 & 9.8 & TBAF & 50 & 165 & 52 & 12100 & 6.3 & 1.11 \\
\hline 8 & $n-\mathrm{Bu}$ & 14 & 8.5 & 10.2 & TBAF & 50 & 268 & 90 & 18200 & 9.8 & 1.10 \\
\hline 9 & $n-\mathrm{Bu}$ & 31 & 40.3 & 9.8 & TBAF & 50 & 270 & 42 & 37600 & 9.3 & 1.08 \\
\hline 10 & $\mathrm{Me}$ & 14 & 40.1 & 10.1 & $\mathrm{KHF}_{2}$ & 24 & 162 & 57 & 7050 & 5.5 & 1.10 \\
\hline 11 & $\mathrm{Me}$ & 14 & 40.1 & 10.5 & $\mathrm{KHF}_{2}$ & 50 & 173 & $65^{\mathrm{e}}$ & 9430 & 7.4 & 1.18 \\
\hline 12 & $\mathrm{Me}$ & 14 & 9.0 & 10.1 & $\mathrm{KHF}_{2}$ & 50 & 235 & 89 & 12300 & 9.7 & 1.12 \\
\hline 13 & $\mathrm{Me}$ & 30 & 9.0 & 10.1 & $\mathrm{KHF}_{2}$ & 50 & 240 & 63 & 17300 & 6.5 & 1.21 \\
\hline
\end{tabular}

${ }^{a}$ Solvent: $\mathrm{THF}(\mathrm{R}=n-\mathrm{Bu}), \mathrm{CH}_{3} \mathrm{CN}(\mathrm{R}=\mathrm{Me}$; Entry 10,12 , and 13$)$, and $\mathrm{CD}_{3} \mathrm{CN}(\mathrm{R}=\mathrm{Me}$; Entry 11$)$. ${ }^{\mathrm{b}} \mathrm{M}$, macromonomer 3; $\mathrm{I}$, initiator (MTS). ${ }^{\mathrm{c}}$ Cat.: catalyst; $[\mathrm{I}]_{0} /[\mathrm{Cat}]_{0}=1020$ (for TBAF) and 10.6 (for $\mathrm{KHF}_{2}$ ). ${ }^{\mathrm{d}}$ Determined by GPC. ${ }^{\mathrm{e}}$ Determined by ${ }^{1} \mathrm{H}$ NMR.

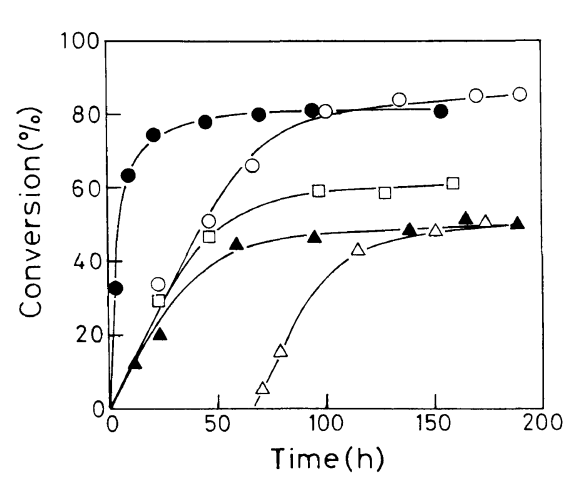

Figure 2. Time versus conversion plots in GTP of MA-PBuOZO-3 at $24 \mathrm{C}$ (Entry 1) (O), MA-PBuOZO-3 at $50 \mathrm{C}$ (Entry 2) (O), MA-PBuOZO-14 at $24 \mathrm{C}($ Entry 7$)(\triangle)$. MA-PBuOZO-14 at $50 \mathrm{C}$ (Entry 8 ) ( $\Delta$ ), and MA-PMeOZO-14 at $24 \mathrm{C}$ (Entry 11 ) ( $\square$ ).

at $40 \mathrm{mmol} \mathrm{L}^{-1}$ at $24^{\circ} \mathrm{C}(\mathrm{R}=\mathrm{Me}$ and $n$-Bu $)$ and $50^{\circ} \mathrm{C}$ $(\mathrm{R}=n-\mathrm{Bu})$ were examined (Figure 2$)$. The polymerization of MA-PMeOZO-14 was conducted in a $5 \mathrm{~mm}$ o.d. NMR tube and conversion was determined by decrease of signal integration of vinyl-methylene protons of methacryloyl group to $\mathrm{OCH}_{2}$ protons at the end of $\mathrm{PMeOZO}$ chain in ${ }^{1} \mathrm{H}$ NMR. The reactivity of MA-PROZO- $n$ (3) was highly influenced by chain length and polymerization temperature. The polymerization rate decreased with increase in $n$, this being consistent with the inference from Figure 1. This is different from that in radical homopolymerization of vinylbenzyl-terminated PROZO macromonomers, in which polymerization rate increased with $n$, due to retardation of bimolecular termination caused by increase in segment density around propagating sites and solution viscosity. ${ }^{11}$ The results for the present polymerizations may be ascribed mainly to depression of propagation reaction by suppression of interpenetration between propagating sites and macromonomers. Effects of the stable radical DPPH on the polymerization in same conditions as Entry 2 (Table II) were examined and this material was found to show no effects. Leveling off of the time versus conversion curves was generally observed, ascribable to suppression of the propagation reactions caused by depressing diffusion of growing chains and macromonomers mainly by increase in solution viscosity.
Polymerization rate at $50^{\circ} \mathrm{C}$ was generally higher than that at $24 \mathrm{C}$. Induction period was observed in a polymerization of $\mathrm{MA}-\mathrm{PBuOZO}-14$ at $24^{\circ} \mathrm{C}$. The retardation of polymerization at $24 \mathrm{C}$ seems due to depression of initiation step. In GTP of methyl methacrylate with MTS, the induction period has been observed and interpreted in terms of slow initiation. ${ }^{12}$ MA-PBuOZO-31 could be polymerized under the same conditions at $50 \mathrm{C}$ to produce $\mathbf{4}$, but did not give any polymer at $24 \mathrm{C}$. These trends on reaction temperature can be explained that diffusion of growing chains and macromonomers is suppressed by drop of temperature. At $-27^{\circ} \mathrm{C}$, PROZO macromonomers could not be polymerized under the present conditions. Under different conditions, polymerization of MA-PMeOZO-14 at $24 \mathrm{C}$ proceeded at higher rate than that of $\mathrm{MA}$ $\mathrm{PBuOZO}-14$ at $50^{\circ} \mathrm{C}$.

The results of GTP under various conditions are shown in Table II. $D P_{n}$ of the poly(MA-PROZO- $n$ )s $\mathbf{4}$ was generally close to the feed ratio $\left([\mathrm{M}]_{0} /[\mathrm{I}]_{0}\right)$, supporting the living nature of polymerization. Higher reaction temperature $\left(50^{\circ} \mathrm{C}\right)$ increased polymerization rate, but also dispersion $\left(M_{w} / M_{n}\right)$. Conversion of macromonomers 3 after enough reaction time increased with decrease in initial concentrations and decreased with increase in chain length $n$. Increase in macromonomer concentration should increase viscosity of polymerization system to retard propagation. Thus, monomer concentration close to $9 \mathrm{mmol} \mathrm{L}^{-1}$ gives higher conversion $(89-95 \%)$ for all macromonomers. Molecular weight distribution of $\mathbf{4}$ obtained from the macromonomers $3(\geq 14)$ was fairly narrow as described above, this being consistent with the living nature of present polymerization. Polymers from MA-PBuOZO-3 showed relatively higher $M_{w} / M_{n}$, due to broad dispersity of macromonomers.

\section{Coupling Reactions of Poly(macromonomer)s}

Coupling reactions of the poly(MA-PBuOZO- $n$ )s 4 produced by GTP of MA-PBuOZO-3 and -14, by utilizing termination with $\mathrm{BMB}$ (Scheme 2) and living PBuOZO $1(n=13)$ (Scheme 3), were examined in situ. The latter reaction (Scheme 3) was mutual termination between living polymers to provide a block copolymer. These termination reactions were carried out in THF at $-78^{\circ} \mathrm{C}$ 


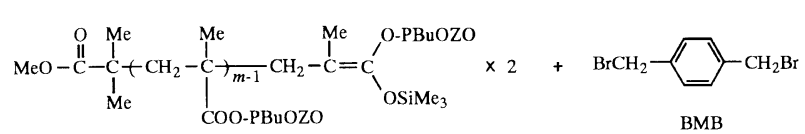

$$
\begin{aligned}
& 4
\end{aligned}
$$

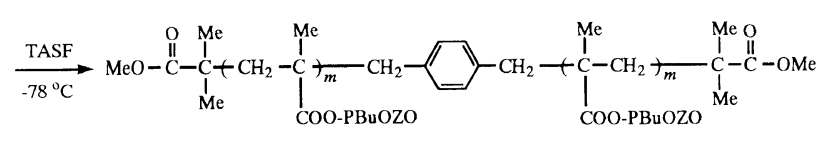

$$
\begin{aligned}
& 5
\end{aligned}
$$

Scheme 2 .

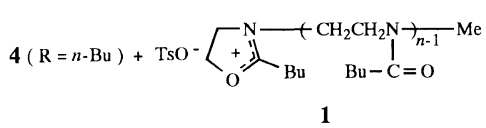

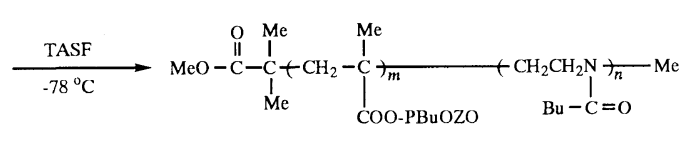

Scheme 3.

\begin{tabular}{|c|c|c|c|c|c|c|c|c|c|}
\hline \multirow{4}{*}{ Entry } & \multicolumn{6}{|c|}{ Group transfer polymerization ${ }^{a}$} & & & \\
\hline & \multicolumn{6}{|c|}{ MA-PBuOZO- $n$} & \multicolumn{3}{|c|}{ Termination $^{c}$} \\
\hline & \multirow{2}{*}{$n$} & $\begin{array}{l}\text { Concen- } \\
\text { tration }\end{array}$ & \multirow{2}{*}{$\frac{[\mathrm{M}]_{0}}{[\mathrm{I}]_{0}}$} & \multirow{2}{*}{$\begin{array}{c}\text { Time } \\
\mathrm{h}\end{array}$} & \multirow{2}{*}{$\begin{array}{c}\text { Conversion }^{\mathrm{b}} \\
\%\end{array}$} & \multirow{2}{*}{$\begin{array}{c}M_{n} \text { of } \\
4^{\mathrm{b}}\end{array}$} & \multirow{2}{*}{$\frac{[\mathrm{BMB}]_{0}}{[\mathrm{I}]_{0}}$} & \multirow{2}{*}{$\begin{array}{c}\begin{array}{c}\text { Conversion } \\
\text { of } \mathbf{4}^{\mathrm{b}}\end{array} \\
\% \%\end{array}$} & \multirow{2}{*}{$\begin{array}{c}M_{n} \text { of } \\
5^{b}\end{array}$} \\
\hline & & $\mathrm{mmol} \mathrm{L}^{-1}$ & & & & & & & \\
\hline 14 & 3 & 83.2 & 7.9 & 48 & 82 & 3500 & 0.50 & 94 & 8800 \\
\hline 15 & 14 & 41.2 & 9.4 & 96 & 50 & 10300 & 0.50 & 96 & 21300 \\
\hline
\end{tabular}

Table III. Termination of living poly(MA-PBuOZO- $n$ )s (4) with BMB

Group transfer polymerization ${ }^{\mathrm{a}}$

${ }^{a} \mathrm{M}$, macromonomer 3; I, initiator (MTS); solvent, THF; catalyst, TBAF $\left([\mathrm{I}]_{\mathrm{o}} /[\mathrm{Cat}]_{0}=1020\right)$; temp, 50 C. ${ }^{\mathrm{b}}$ Determined by GPC.

\begin{tabular}{|c|c|c|c|c|c|c|c|c|c|c|c|}
\hline \multirow{4}{*}{ Entry } & \multicolumn{6}{|c|}{ Group transfer polymerization ${ }^{\mathrm{a}}$} & \multirow{2}{*}{\multicolumn{2}{|c|}{$\begin{array}{l}\text { Polymerization }^{\mathrm{c}} \\
\text { of } \mathrm{BuOZO}\end{array}$}} & \multirow{2}{*}{\multicolumn{3}{|c|}{ Termination $^{d}$}} \\
\hline & \multicolumn{2}{|c|}{ MA-PBuOZO- $n$} & \multirow[b]{2}{*}[\mathrm{M}]{$_{0}$} & \multirow[b]{2}{*}{ Time } & \multirow[b]{2}{*}{$\begin{array}{l}\text { Con- } \\
\text { version }^{b}\end{array}$} & \multirow{3}{*}{$\begin{array}{c}M_{n} \text { of } \\
\mathbf{4}^{\mathrm{b}}\end{array}$} & & & & & \\
\hline & \multirow{2}{*}{$n$} & $\begin{array}{l}\text { Concent- } \\
\text { ration }\end{array}$ & & & & & {$[\mathrm{BuOZO}]_{0}$} & $M_{n}$ of & {$[\mathrm{MeOTs}]_{0}$} & $\begin{array}{l}\text { Conver- } \\
\text { sion of } 4^{b}\end{array}$ & $M_{n}$ of \\
\hline & & $\mathrm{mmol} \mathrm{L}^{-1}$ & {$[\mathrm{I}]_{0}$} & $\mathrm{~h}$ & $\%$ & & {$[\mathrm{MeOTs}]_{0}$} & & {$[\mathrm{I}]_{0}$} & $\%$ & \\
\hline 16 & 3 & 86.3 & 17.9 & 72 & 74 & 8200 & 13.1 & 1820 & 1.05 & 100 & 12600 \\
\hline 17 & 14 & 40.6 & 9.7 & 96 & 48 & 10700 & 13.1 & 1820 & 1.03 & 100 & 13500 \\
\hline
\end{tabular}
${ }^{\mathrm{c}}[\mathrm{TASF}]_{0} /[\mathrm{I}]_{0}=1.27$; temp, $-78^{\circ} \mathrm{C}$; time, $24 \mathrm{~h}$.

Table IV. Termination of living poly(MA-PBuOZO-n)s (4) with living PBuOZO (1)

${ }^{\mathrm{a}} \mathrm{M}$, macromonomer 3; I, initiator (MTS); solvent, THF; catalyst, TBAF $\left([\mathrm{I}]_{0} /[\mathrm{Cat}]_{0}=1020\right)$; temp, $50^{\circ} \mathrm{C}$. ${ }^{\mathrm{b}} \mathrm{Determined}$ by GPC. ${ }^{\mathrm{c}} \mathrm{BuOZO}$ was polymerized using MeOTs as an initiator in $\mathrm{CH}_{3} \mathrm{CN}$ by heating at $80^{\circ} \mathrm{C}$ for $24 \mathrm{~h}$. ${ }^{\mathrm{d}}[\mathrm{TASF}]_{0} /[\mathrm{I}]_{0}=1.23$; temp, $-78^{\circ} \mathrm{C}$; time, $24 \mathrm{~h}$.

using TASF as catalyst in amounts of more than equimolar with MTS by reference to the coupling reaction of living poly(methyl methacrylate) performed by Sogah. ${ }^{10}$ Though the polymers of MA-PMeOZO-14 were examined for coupling reactions in $\mathrm{CH}_{3} \mathrm{CN}$ using respective TASF and $\mathrm{KHF}_{2}$ as the catalysts at $-78^{\circ} \mathrm{C}$, no coupling product was detected.

As shown in Table III, to a solution of poly(MAPBuOZO- $n$ )s (4) given from MA-PBuOZO-3 and -14, $\mathrm{BMB}$ was added in situ under argon in the presence of TASF and stirred for $24 \mathrm{~h}$. Products with nearly twice $M_{n}$ of the feed polymers 4 were obtained in the conversion of 94 and $96 \%$, showing formation of the coupled polymers (5) and living nature of 4 (Figure 3 (a)).

For mutual termination (Table IV), $1(\mathrm{R}=\mathrm{Bu} ; n=13$; $M_{n}=1820$ ) was prepared by polymerization of $\mathrm{BuOZO}$ using MeOTs as an initiator in $\mathrm{CH}_{3} \mathrm{CN}$. This polymerization solution was added in situ to polymerization solutions of poly(MA-PBuOZO- $n$ )s 4 provided from $\mathrm{MA}-\mathrm{PBuOZO}-3$ and -14 in the presence of TASF and stirred for $24 \mathrm{~h}$.

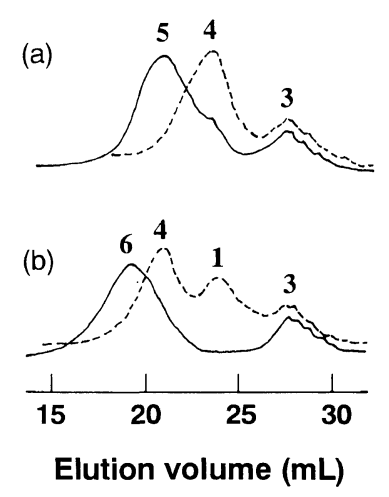

Figure 3. GPC curves of termination products of living poly(MAPBuOZO-3) (4). (a) Entry 14: termination with BMB. (b) Entry 16: termination with living PBuOZO $1(n=13)$. mixture after termination; -..-.--, feed mixture.

In GPC of reaction products (Figure $3(b)$ ), only peaks of coupling products and residual macromonomers in GTP were observed and living polymer peaks were not 
detected. $M_{n}$ of the products (6) (12600 and 13500) were reasonably higher than those (8200 and 10700) of $\mathbf{4}$, showing formation of block copolymers. Previously, living PROZO was end-capped by terminating the propagating species (2-oxazolinium salts) with various nucleophiles to give end-functionalized polymers, i.e., telechelic polymers. ${ }^{2,13}$ It is of interest that the living ends of PROZO can be terminated by propagating species of GTP of the MA-PROZO macromonomers. The block copolymers produced by coupling reaction possess a characteristic structure of a multi-branched moiety and linear chain.

\section{CONCLUSIONS}

GTP of MA-PROZO macromonomers (3; MAPROZO- $n$ ) by MTS as the initiator using TBAF (for MA-PBuOZO- $n$ ) and $\mathrm{KHF}_{2}$ (for MA-PMeOZO- $n$ ) as catalysts, produced poly (MA-PROZO- $n$ )s 4 with $M_{n}$ up to 37600 . Molecular weight distribution of $\mathbf{4}$ from $\mathbf{3}$ of $n \geq 14$ was fairly narrow, i.e., $M_{w} / M_{n}=1.08-1.12$. Rate of GTP decreased with increase in $n$ and concentration of macromonomers, the reverse of that of radical polymerization. Maximum conversion of each macromonomers was obtained at relatively lower concentration of 3, generally $89-95 \%$. Poly(MA-PBuOZO- $n$ )s 4 were reacted in situ with $\mathrm{BMB}$ and propagating species of living $\mathrm{PBuOZO}$ to provide chain extended poly(macromonomer)s (5) or block copolymers (6). The reactivity of macromonomers 3 and poly(macromonomer)s 4 and narrow molecular weight distribution of $\mathbf{4}$ indicated the living nature of present polymerization.

\section{REFERENCES}

1. (a) S. Kobayashi and T. Saegusa, in "Ring-Opening Polymerization," Vol. 2, K. J. Ivin and T. Saegusa, Eds., Elsevier Applied Science Publishers Ltd., London, 1984, p 764. (b) S. Kobayashi, Prog. Polvm. Sci., 15, 751 (1990). (c) H. Uyama and S. Kobayashi, in "Catalysis in Precision Polymerization," S. Kobayashi Ed., John Wiley \& Sons, Inc., Chichester, 1997, p 399.

2. S. Kobayashi, E. Masuda, S. Shoda, and Y. Shimano, Macromolecules, 22, 2878 (1989).

3. S. Shoda, E. Masuda, M. Furukawa, and S. Kobayashi, J. Polvm. Sci., Part A, Polym. Chem., 30, 1489 (1992).

4. Y. Shimano, K. Sato, and S. Kobayashi, Polym. J., 31, 219 (1999).

5. Y. Shimano, K. Sato, D. Fukui, Y. Onodera, and Y. Kimura, Polym. J., 31, 296 (1999)

6. O. W. Webster, W. R. Hertler, D. Y. Sogah, W. B. Farnham, and T. V. Rajanbabu, J. Am. Chem. Soc., 105, 5706 (1983).

7. R. Asami, M. Takaki, and Y. Moriyama, Polym. Bull., 16, 125 (1986).

8. H. Witte and W. Seeliger, Liebigs Ann. Chem., 996 (1974).

9. C. Ainsworth, F. Chen, and Y.-N. Kuo, J. Organomet. Chem., 46, 59 (1972).

10. D. Y. Sogah, W. R. Hertler, O. W. Webster, and G. M. Cohen, Macromolecules, 20, 1473 (1987).

11. Y. Tsukahara, K. Tsutsumi, Y. Yamashita, and S. Shimada, Macromolecules, 23, 5201 (1990).

12. (a) A. H. E. Müller, Makromol. Chem., Macromol. Symp., 32, 87 (1990). (b) U. Schmalbrock, H. Sitz, and F. Bandermann, Makromol. Chem., 190, 2713 (1989).

13. (a) S. Kobayashi, T. Mizutani, and T. Saegusa, Makromol. Chem., 185, 441 (1984). (b) Y. Shimano, K. Sato, and S. Kobayashi, $J$. Polym. Sci., Part A, Polym. Chem., 33, 2715 (1995). (c) M. Miyamoto, K. Naka, M. Tokumizu, and T. Saegusa, Macromolecules, 22, 1604 (1989). 